\title{
Pectinase Production by Fungal Strains in Solid-State Fermentation Using Agro-Industrial Bioproduct
}

\author{
Natalia Martin, Simone Regina de Souza, Roberto da Silva and Eleni Gomes * \\ Laboratório de Bioquímica e Microbiologia Aplicada; IBILCE; UNESP; Rua Cristóvão Colombo, 2265; \\ Jd. Nazareth; 15054-000; São José do Rio Preto - SP - Brazil
}

\begin{abstract}
Pectin lyase and polygalacturonase production by newly isolated fungal strains was carried out in solid-state fermentation. Moniliella SB9 and Penicillium sp EGC5 produced polygalcturonase $(P G)$ and pectin lyase $(P L)$ on mixture of orange bagasse, sugar cane bagasse and wheat bran as substrate. PG and PL produced by Moniliella presented optimum activity at $\mathrm{pH} 4.5$ and 10.0 and at 55 and $45^{\circ} \mathrm{C}$, respectively, while these enzymes from Penicillium sp presented optimum activity at $\mathrm{pH} 4.5-5.0$ and 9.0 and $40^{\circ} \mathrm{C}$, respectively.
\end{abstract}

Key words: Penicillium, Moniliella, polygalacturonase, pectin lyase

\section{INTRODUCTION}

Solid-state fermentation is traditionally defined as those processes in which microbial growth and products formation occur on the surfaces of solid substrates in the near absence of free water. Due to this low amount of water available in solid-state bioprocessing, the class of microorganisms that are most commonly used is fungi (Zheng and Shetty, 2000; Pandey et al., 2001). Several agro-industrial waste and by-products such as orange bagasse (Martins et al, 2002), sugar cane bagasse (Silva et al., 2002) wheat bran (Cavalitto et al., 1996) and other food processing waste (Zheng and Shetty,2000) are effective substrates for depolymerizing enzyme production by solid-state fermentation.

Recently, a large number of microorganisms, isolated from different materials, have been screened for their ability to degrade polysaccharide present in vegetable biomass producing pectinases on solid-state culture (Soares et al, 2001; Gomes et al., 2001).

Pectinolytic enzymes are classified according to their way of attack on the galacturonan part of the pectin molecule. They can be distinguished between pectin methylesterases (EC 3.1.11.1) that deesterify pectins to low methoxyl pectins or pectic acid, and pectin depolymerases, which split the glycosidic linkages between galacturonosyl (methyl ester) residues. Polygalacturonases split glycosidic linkage next to free carboxyl groups by hydrolysis while pectate lyase split glycosidic linkages next to free carboxyl groups by $\beta$-elimination. Both endo types of PGs and PALs (EC 3.2.1.15 and EC 4.2.2.2, respectively) are known by spliting randomly the pectin chain. ExoPGs (EC 3.2.1.67) release monomers or dimmers from the non-reducing end of the chain, whereas exo-PALs (EC 4.2.2.9) release unsaturated dimmers from the reducing end. Highly methylated pectins are degraded by endo-pectin lyases (PL; EC 4.2.2.10) and also by a

\footnotetext{
* Author for correspondence
} 
combination of PE with PG or PAL (Sarkanen et al, 1991, Pilnik and Voragen, 1993).

The aim of this work was to study of pectolytic enzymes production by newly isolated strains of fungi by solid-state fermentation using agroindustrial by-products. Some physico-chemical characteristics of the enzymes produced have been discussed.

\section{MATERIAL AND METHODS}

\section{Microorganisms}

The fungal strains used in this study were recently isolated from decaying vegetable and soil. Samples ( $2 \mathrm{~g}$ ) from agricultural soil and decaying vegetable were pooled and homogenized in sterile medium containing $1 \%$ of citrus pectin; $0.14 \%$ of $\left(\mathrm{NH}_{4}\right)_{2} \mathrm{SO}_{4} ; \quad 0.20 \%$ of $\mathrm{K}_{2} \mathrm{HPO}_{4} ; \quad 0.02 \%$ of $\mathrm{MgSO}_{4} .7 \mathrm{H}_{2} \mathrm{O} ; 0.10 \%$ of nutrient solution $(5 \mathrm{mg} / \mathrm{l}$ $\mathrm{FeSO}_{4} .7 \mathrm{H}_{2} \mathrm{O} ; 1.6 \mathrm{mg} / \mathrm{l} \quad \mathrm{MnSO}_{4} \cdot \mathrm{H}_{2} \mathrm{O} ; 1.4 \mathrm{mg} / \mathrm{l}$ $\mathrm{ZnSO}_{4} .7 \mathrm{H}_{2} \mathrm{O} ; 2.0 \mathrm{mg} / \mathrm{l} \mathrm{CoCl}_{2}$ ), pH 5.0. The mixture was incubated at $30^{\circ} \mathrm{C}$ for $24 \mathrm{~h}$ and a loop of the homogenized one was then streaked onto the same medium, containing agar $3 \%$ and incubated at $30^{\circ} \mathrm{C}$ for 24 to $72 \mathrm{~h}$. All morphological contrasting colonies were purified by repeated streaking. Identification of genus was based on morphological and biochemical characteristics (Hawksworth et al., 1983). and they were maintained on PDA slopes as a stock culture.

\section{Media, cultivation of microorganism and enzyme production}

The solid substrates were prepared as follows:

a) Orange bagasse. The pellet of orange bagasse (pressed mixture of pulp and peel) was provided by Citrovita Agro-industrial Ltda/ Catanduva/SP/ Brazil. Chemical analysis revealed that the dry material was composed of $11.8 \%$ fiber, $6.3 \%$ nitrogen, $6.7 \%$ ash, $19 \%$ total sugar (9\% reducing sugar) and $0.1 \%$ pectin. The material was ground and particles sieved by a Bender USS 230 strainer and dried at $80^{\circ} \mathrm{C}$.

b) Sugar cane bagasse: Sugar cane bagasse was provided by Usina de Açúcar e Álcool São Domingos / Catanduva/ SP/Brasil. Chemical analysis revealed that the dry material was composed of $75 \%$ fiber, $5 \%$ nitrogen, $3.4 \%$ ash, $10.36 \%$ total sugar $(3.53 \%$ reducing sugar). The material was washed in tap water and the same procedure described above was followed.

c) Wheat bran: Wheat bran was obtained commercially, dried and used untreated. Chemical analysis revealed that the dry material was composed of $8.12 \%$ fiber, $6.5 \%$ nitrogen, $4.57 \%$ ash, $16.7 \%$ total sugar $(5.22 \%$ reducing sugar).

The substrates for fermentations consisted of sugar cane bagasse and wheat bran mixtures in proportions of 1:9 and 9:1, respectively, and of sugar cane bagasse, orange bagasse and wheat bran in proportions of $1: 1: 1$.

Solid-state fermentation (SSF) was carried out using a $250 \mathrm{~mL}$ Erlenmeyer flask containing $5 \mathrm{~g}$ of sterilized substrate $\left(120^{\circ} \mathrm{C} / 40 \mathrm{~min}\right)$ inoculated with $10 \mathrm{~mL}$ aliquots of conidia suspension (approx.10 spore/g dry substrate) which was obtained from a 7-day agar slant culture suspended in sterile Tween 80 solution. After inoculation, $10 \mathrm{~mL}$ of nutrient solution, composed of $0.1 \% \quad \mathrm{NH}_{4} \mathrm{NO}_{3}$; $0.1 \% \quad \mathrm{NH}_{4} \mathrm{H}_{2} \mathrm{PO}_{4} ; 0.1 \% \quad \mathrm{MgSO}_{4} \times 7 \mathrm{H}_{2} \mathrm{O}$, were added to each of the flasks. The final moisture content of the medium was approximately $67 \%$.

The cultivation was carried out at $30^{\circ} \mathrm{C}$ for 15 days. At $24 \mathrm{~h}$ intervals the solid fermented material, corresponding to one Erlenmeyer flask, was mixed with $30 \mathrm{~mL}$ of distilled water $(6 \mathrm{~g}$ of fermented material $/ \mathrm{mL}$ ), stirred for $40 \mathrm{~min}$, filtered under vacuum and centrifuged. The supernatant was used as crude enzyme solution.

\section{Enzyme activity measurements}

Polygalacturonase (PG) activity was determined by measuring the release of reducing groups from citrus pectin using the 3,5-dinitrosalicylic acid (DNS) reagent assay (Miller, 1959). The reaction mixture containing $0.8 \mathrm{~mL} 1 \%$ citric pectin $67 \%$ methoxylated (Braspectina-Limeira/SP/Br) in $0.2 \mathrm{M}$ acetate buffer, $\mathrm{pH} 5.0$ and $0.2 \mathrm{~mL}$ of crude enzyme solution, was incubated at $40^{\circ} \mathrm{C}$ for $10 \mathrm{~min}$ (Soares et al., 1999). One unit of enzymatic activity (U) was defined as the amount of enzyme which released one $\mu \mathrm{mol}$ of galacturonic acid per minute.

Pectin lyase $(\mathrm{Pl})$ activity was determined by measuring the increase in absorbance at $235 \mathrm{~nm}$ of substrate solution $(0.8 \mathrm{~mL} 1 \%$ citric pectin in $0.2 \mathrm{M}$ tris- $\mathrm{HCl}$ buffer, $\mathrm{pH} 8.5$ ) hydrolyzed by 0.2 $\mathrm{mL}$ enzyme solution, at $40^{\circ} \mathrm{C}$. One unit of enzymatic activity (U) was defined as the amount 
of enzyme which released $1 \mu \mathrm{mol}$ of unsaturated uronide per minute, based on the molar extinction coefficient (5500) of the unsaturated products (Albersheim, 1966).The enzyme production was expressed in units per gram of initial dry solid substrate $\left(\mathrm{Ug}^{-1}\right)$.

\section{Enzyme characterization}

The fractions of PG and PL, obtained from gel filtration, were used for characterization assay (Silva et al., 2002).

Optimum $p H$ and temperatures for enzyme activity: The enzyme activity was determined at $50^{\circ} \mathrm{C}$, in different $\mathrm{pH}$ using as buffers sodium acetate $(\mathrm{pH} 3.0-5.0)$, citrate-phosphate $(\mathrm{pH} 5.0$ 7.0), tris- $\mathrm{HCl}(\mathrm{pH} 7.0-8.5)$ and glycine- $\mathrm{NaOH}(\mathrm{pH}$ 8.5-11.0). The optimum temperature was assayed by incubation of the reaction mixture at temperature of $30-70{ }^{\circ} \mathrm{C}$ at optimum $\mathrm{pH}$.

$\mathrm{pH}$ and temperature stability: Enzyme solution was dispersed (1:1) in $0.2 \mathrm{M}$ buffer $\mathrm{pH} 3.0-5.0$ (sodium acetate), $\mathrm{pH}$ 5.0-7.0 (citrate-phosphate), $\mathrm{pH}$ 7.0-8.5 (tris- $\mathrm{HCl}$ ) and $\mathrm{pH}$ 8.5-11.0 (glycine$\mathrm{NaOH})$ and maintained at $25^{\circ} \mathrm{C}$ for $24 \mathrm{~h}$. An aliquot was used to determine the remaining activity at the optimum $\mathrm{pH}$ and temperature for enzymes. For the temperature stability determination, the enzyme solution was incubated at different temperatures $\left(30^{\circ} \mathrm{C}-70^{\circ} \mathrm{C}\right)$ for $1 \mathrm{~h}$ at $\mathrm{pH}$ 5.0. An aliquot was withdrawn and placed on ice before assaying for residual pectinase activity at optimum $\mathrm{pH}$ and temperature.

\section{RESULTS AND DISCUSSION}

\section{Production of pectinases in SSF}

Initially sixteen strains of fungi isolated from decaying vegetable and soil sample were cultivated in the mixture of sugar cane bagasse and wheat bran in proportions of 1:9 and 9:1 (medium A and B, respectively) for 15 days. Data of Table1 showed that synthesis of polygalacturonase and pectin lyase by all the fungi tested depended upon the proportions of mixture used. For majority of strains (thirteen) a higher PG activity was observed in medium $\mathrm{B}$, indicating that media containing the highest pectin (orange bagasse) and nutrient concentration (wheat bran) resulted higher production of this enzyme. On the other hand, PL production depended on the strain used. PL activity was higher in the medium containing higher proportion of wheat bran (medium B) in fermentation using eight strains, whereas other seven strains presented higher production in medium composed by mixture of sugar cane bagasse and wheat bran in proportion of 9:1(medium A).

According Silva et al. (2002) PG and PL production by $P$. viridicatum RFC3 using orange bagasse and sugar cane bagasse was influenced by media composition, reaching higher value in mixture containing wheat bran. The effect of different carbon source on pectinase synthesis by fungi in submerged and solid-state fermentation have been studied.

Table1 - Production of pectinases by isolated fungal strains by FSS

\begin{tabular}{|c|c|c|c|c|}
\hline \multirow{2}{*}{ Strain } & \multicolumn{2}{|c|}{ PI (U/g) } & \multicolumn{2}{|c|}{$\operatorname{Pg}(\mathrm{U} / \mathrm{g})$} \\
\hline & $\mathbf{A}$ & B & $\mathbf{A}$ & B \\
\hline Moniliellla sp SB9 & 16800.0 & 18740.0 & 3.2 & 21.0 \\
\hline Penicillium sp EGC5 & 2540.0 & 9250.0 & 8.7 & 11.0 \\
\hline P. viridicatum $\mathrm{RFC} 3$ & $\mathrm{Nd}$ & 656.0 & 1.5 & 19.0 \\
\hline P. glabum $\mathrm{F} 1$ & 51.0 & $\mathrm{Nd}$ & 14.4 & 5.1 \\
\hline Penicillium sp RFC 2 & 1002.0 & $\mathrm{Nd}$ & 7.2 & 10.2 \\
\hline P. itallicum & 876.0 & $\mathrm{~N} \mathrm{~d}$ & 16.0 & 16.0 \\
\hline P. citrinum & 602.0 & $\mathrm{Nd}$ & 7.8 & 3.0 \\
\hline Curvularia inaequalis EM P11-1 & 372.0 & $\mathrm{Nd}$ & 8.0 & 15.0 \\
\hline Curvularia sp 5.11 .1 & $\mathrm{Nd}$ & $\mathrm{Nd}$ & 2.0 & 3.0 \\
\hline Aspergillus sp EG66F & 894.0 & 83.0 & 10.2 & 15.0 \\
\hline Aspergillus sp EGC4 & 330.0 & 1518.0 & 2.4 & 11.4 \\
\hline$A$. niger & 39.0 & 288.0 & 3.6 & 9.0 \\
\hline Thermoascus sp 179.5 & 368.0 & 222.0 & 27.0 & 34.0 \\
\hline Aureobasidium sp RE & $\mathrm{Nd}$ & 81.0 & 1.0 & 9.0 \\
\hline Phanerochaetes sp 291 & $\mathrm{Nd}$ & 720.0 & 6.0 & 21.0 \\
\hline Cladosporium sp RFC 1 & $\mathrm{Nd}$ & 56.0 & 8.4 & 11.0 \\
\hline
\end{tabular}

Medium A =sugar cane bagasse $90 \%$ wheat bran 10\%; Medium B= Wheat bran 90\%, sugar cane bagasse $10 \%$ 
It is generally agreed that the optimum medium for the enhanced production of extracellular pectinase is that containing pectic materials as an inducer (Galiotou-Panayotou et al., 1993; Crotti et al., 1999).

Among the fungi studied Moniliella sp SB9 and Penicillium sp EGC5 presented high production of $\mathrm{Pl}$ and considerable quantities of PG in both media (Table 1) being selected for a second stage of assays which both the fungi were cultivated in mixture composed by orange bagasse, sugar cane bagasse and wheat bran in proportion of 1:1:1. Enzyme production in SSF was analyzed during 15 days and the data of Fig. 1 corresponded to mean of five assays. Polygalacturonase production by Moniliella sp peaked between $3^{\text {th }}$ and $4^{\text {th }}$ days of cultivation, with the maximum activity of PG $26 \mathrm{Uxg}^{-1}$. The maximum PL activity (19400 $\mathrm{Uxg}^{-1}$ ) was observed at the $6^{\text {th }}$ day (Fig. 1a). When Penicillium sp EGC5 was used maximal $\mathrm{Pg}$ activity $\left(12 \mathrm{Uxg}^{-1}\right)$ was detected at the $8^{\text {th }}$ day and PL activity, at the $4^{\text {th }}$ day (11000 $\mathrm{Uxg}^{-1}$ ) (Fig. 1b). The different peaks of enzymatic activity observed in both cultivation indicated a sequential production of isoenzymes by fungi as described by several authors (Fonseca and Said, 1995, Leone and Heuvel, 1987, Silva et al., 2002, Martin et al., 2002).

Addition of fibrous material as sugar cane bagasse, resulted in the interparticle spacing with a possible increase in the aeration and nutrients and enzyme diffusion (Mitchell et al., 1991). When sugar cane bagasse was used as the sole carbon source, the growth of the fungi was low (data not shown) indicating that microorganisms was not able to hydrolyses cellulose and hemicellulose fibers enough to support of the mycelium formation. This supposition was confirmed by low level of cellulase $\left(0.24 \mathrm{Uxg}^{-1}\right.$ for Moniliella sp and not detected in Penicillium sp ECG5 cultivation medium) and xilanase (15.5 $\mathrm{Uxg}^{-1}$ for Moniliella sp and $12 \mathrm{Uxg}^{-1}$ for Penicillium sp ECG5) produced in the experiments. Apparently, sugar cane bagasse acted as only a solid inert support and the microbial growth and enzyme production were stimulated by wheat bran and orange bagasse. The use of sugar cane bagasse as inert support was suitable for the growth and pectinase production by Aspergillus niger, $P$. viridicatum RFC3 and Thermoascus aurantiacus (Oriol et al, 1988; Silva et al., 2002; Martins et al., 2002).

The quantities of PG and PL obtained in this study were high compared to those reported for pectinolytic strains such as Aspergillus niger (25 U $\mathrm{Pg}$ and $350 \mathrm{U} \mathrm{Pl}$ per gram of substrate), $P$. italicum $(6 \mathrm{U} \mathrm{Pl} / \mathrm{g}$ e $25 \mathrm{U} \mathrm{Pg} / \mathrm{g})$, P. frequentans $(3.4$ $\mathrm{U} \mathrm{Pg} / \mathrm{g}$ ) and A. foedidus (1000 U Pl/g) cultivated on solid substrates (Garzón and Hours, 1992; Hours et al., 1994; Castilho et al, 2000). However, the comparison of the amounts of enzyme produced by different organisms is not absolutely adequate, because different culture conditions have been used. These results showed that SSF was suitable for pectinase production by the several fungal strains studied.

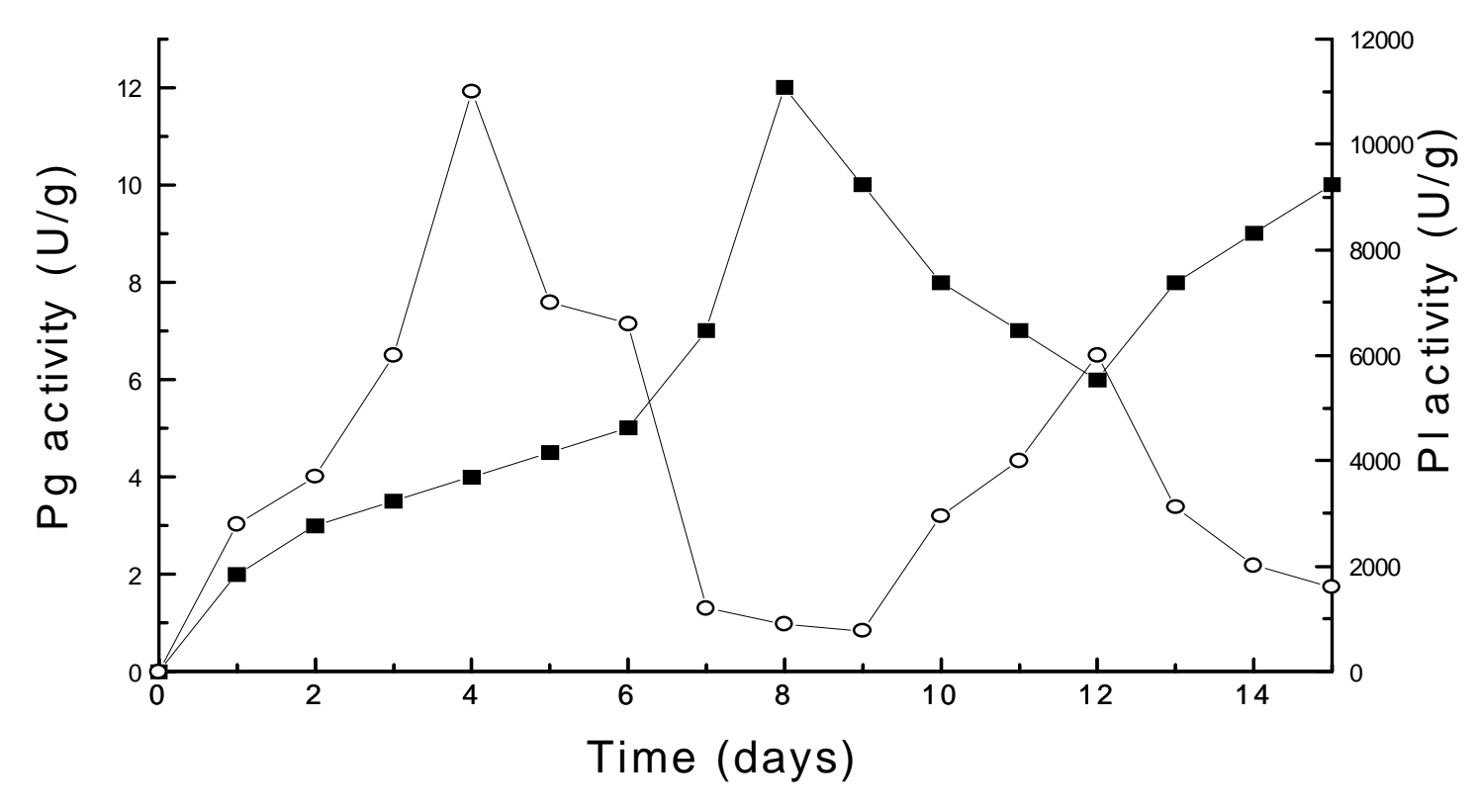

$1 \mathbf{a}$ 


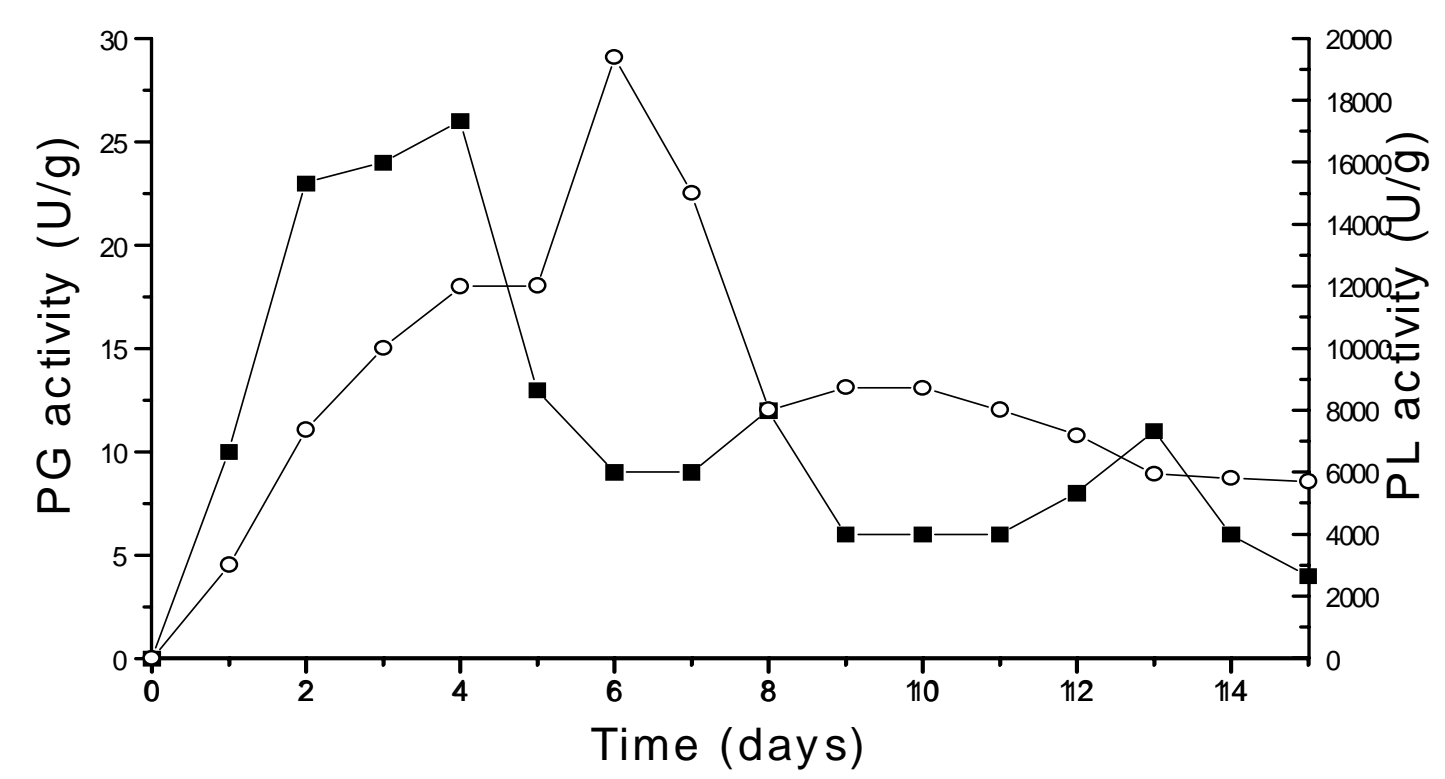

1b

Figure 1 - Pectinase production by Moniliella sp SB9 (a) and Penicillium sp EGC5 (b) on orange bagasse, sugar cane bagasse and wheat bran mixture (1: 1:1). full Symbol = Polygalacturonase; open symbol =Pectin lyase

\section{Enzyme characterization}

Characterization of fraction of the polygalacturonase and pectin lyase obtained from Moniliella sp SB9 and Penicillium sp EGC5 cultivation was carried out. PG from Moniliella sp showed maximum activity at $\mathrm{pH} 4.5$ and $\mathrm{PL}$ at $\mathrm{pH}$ 10.0, whereas PG and PL from Penicillium sp EGC5 presented optimum $\mathrm{pH}$ at 4.5-5.0 and 9.0, respectively. Enzymes from Moniliella were stable at $\mathrm{pH}$ 3.0-10.0 (PG) and 4.0-7.0 (PL) and their activity was preserved $70 \%$ when maintained at $60^{\circ} \mathrm{C}$ for $1 \mathrm{~h}$. PG from Penicillium sp was stable at $\mathrm{pH}$ range of 3.0-8.0 and maintained $70 \%$ of initial activity at $70^{\circ} \mathrm{C}$. $\mathrm{Pl}$ produced by this microorganism was stable in acidic to neutral $\mathrm{pH}$ (4.0-7.0) and was stable in temperature lower than $40^{\circ} \mathrm{C}$ (Table 2).

The physico-chemical characteristics of pectinases from microorganisms studied were similar those reported for several fungal species (Riou et al, 1992, Ryazanova et al, 1996, Blanco et al., 1999).

Table 2 - Characteristics of pectinase produced by Moniliella sp SB9 and Penicillium sp EGC5 on SSF

\begin{tabular}{lrrrr}
\hline \multirow{2}{*}{ Characteristics } & \multicolumn{2}{c}{ Moniliella sp SB9 } & \multicolumn{2}{c}{ Penicillium sp EGC5 } \\
\cline { 2 - 5 } & \multicolumn{1}{c}{ Pg } & \multicolumn{1}{c}{ PI } & \multicolumn{1}{c}{ PI } \\
\hline Optimum pH & 4.5 & 10.0 & $4.5-5.0$ & 9.0 \\
Optimum temperature $\left({ }^{\circ} \mathrm{C}\right)$ & 55 & 45 & 40 & 40 \\
pH range which preserving $70-100 \%$ of & $3.0-10.0$ & $4.0-7.0$ & $3.0-8.0$ & $4.0-5.0$ \\
$\begin{array}{l}\text { initial activity } \\
\text { Temperature range }\left({ }^{\circ} \mathrm{C}\right) \text { which preserving }\end{array}$ & $10-60$ & $10-60$ & $10-70$ & $10-40$ \\
$70-100 \%$ of initial activity & & & & \\
\hline
\end{tabular}




\section{RESUMO}

A produção de pectina liase e poligalacturonase por linhagens de fungos filamentosos isoladas, foi estudada através de fermentação em estado sólido utilizando subprodutos agro-industriais. Os fungos Moniliella sp SB9 e Penicillium sp EGC5 produziram consideráveis quantidades de PG e PL em substrato composto por mistura de bagaço de laranja, bagaço de cana de açúcar e farelo de trigo (1:1:1). As enzimas PG e PL, produzidas por Moniliella sp, apresentaram atividades ótimas em $\mathrm{pH}$ de 4,5 e 10,0 e em temperaturas de $55^{\circ} \mathrm{C}$ e $45^{\circ} \mathrm{C}$, respectivamente. As mesmas enzimas, produzidas por Penicillium sp apresentaram atividades ótimas em $\mathrm{pH} 4,5-5,9$ e 9,0 e $40^{\circ} \mathrm{C}$, respectivamente.

\section{ACKNOWLEDGEMENTS}

The authors wish to thank the Fundação de Amparo à Pesquisa do Estado de São Paulo (FAPESP) for financial support.

\section{REFEERENCES}

Albersheim, P. (1966), Pectin lyase from fungi. Methods Enzymol., 8, 628-631.

Blanco, P.; Sieiro, C. and Villa, T. G. (1999), Production of pectic enzymes in yeasts. FEMS Microbiology Letters, 175, 1-9.

Castilho, L. R.; Alves, T. L. M. and Medronho, R. A (2000), Production and extraction of pectinases obtained by solid state fermentation of agro-industrial residues with Aspergillus niger. Bioresource Technol., 71, 45-50.

Cavalitto, S. F.; Arcas, J. A. and Hours, R.A, (1996), Pectinase production profile of Aspergillus foedidus in solid state cultures at different acidities. Biotechnology Letter, 18, 251-256.

Crotti, L. B.; Jabopr, V. A.; Chellegatti, M. A.; Fonseca, M. J. and Said, S. (1999), Studies of pectic enzymes produced by Talaromyces flavus in submerged and solid substrate cultures. J. Basic Microbiol., 39, 227-35.

Fonseca, M. J. V. and Said, S. (1995) Sequential production of pectinases by Penicillium frequentans. World J.microbial. Biotecnol., 11, 174-177.

Galiotou-Panayotou, M.; Rodis, P. and Kapantai, M (1993), Enhanced polygalacturonase production by Aspergillus niger NRRL-364 grown on supplemented citrus pectin. Letters Apll. Microbiol., 17, 145-148.
Garzón, C. G. and Hours, R. A. (1992), Citrus waste: an alternative substrate for pectinase production in solidstate culture. Biores. Technol., 39, 93-95.

Gomes, E.; Iembo, T. and Silva, R. (2001), Production, characterization and properties of depolymerising enzymes from a Curvularia inaequalis strains, Folia Microbiologica, 46, 303-308.

Hawksworth, D. L.; Sutton, B. C. and Ainsworth, G. C. (1983), Ainsworth and Bisby's Dictionary of the Fungi. Kew : Commonwealth Mycological Institute.

Hours, R. A.; Voget, C. E. and Ertola, R. J. (1988), Some factories affecting pectinase production from apple pomace in solid states cultures. Biological wastes., 24,147-157.

Leone, G. and Heuvel V. D. (1987), Regulation by carbohydrates of the sequential in vitro production of pectic enzymes by Botrytis cinerea. Ca. J. Bot., 65, 2133-2141.

Martins, E. S.; Silva, R. and Gomes, E. (2000), Solid state production of thermostable pectinases from thermophilic Thermoascus aurantiacus. Process Biochem., 37, 949-954.

Miller, G. L. (1959), Use of dinitrossalicylic acid reagent for determination of reducing sugars. Anal Chem., 31, 426-428.

Mitchell, D. A.; Do, D. D.; Greenfield, P. F. and Doelle, H. W. (1991), A semi-mechanistic mathematical model for growth of Rhizopus oligosporus in a model solid-state fermentation system. Biotechnol. Bioeng., 38, 35362.

Oriol, E.; Schettino, B.; Viniegra-Gonzales, G. and Raimbaut, M. (1988), Solid-state culture of Aspergillus niger on support. J. Ferment. Technol., 66,57-62.

Pandey, A.; Soccol, C. R.; Nigam, P. and Soccol, V. T. (2000), Biotechnological potential of agro-industrial residues. I: sugar cane bagasse. Bioresource Technol., 74,69-80.

Pilnik, W. and Voragen, A. G. J. (1993), Pectic enzymes in fruit and vegetable juice manufature. In: Nagodawithama, T. and Reed, G. (Eds.). Enzymes in Food Processing. New York : Academic Press. pp 363-399.

Riou, C.; Freyssinet, G. and Feure, M. (1992), Purification and characterization of extracellular pectinolytic enzymes produced by Sclerotinia sclerotiorum. Appl. Env. Microbiol., 58, 578-583.

Ryazanova, L.P.; Mikhaleva, N.I.; Solov'eva, I.V.; Boev, A.V.; Okunev, O.N.; Kulaev, I.S. (1996), Pectolytic enzymes from Aspergillus heteromorphus. Appl. Biochem. Microbiol., 32, 1-6.

Sarkanen, S. (1991), Enzymatic lignin degradation: an extracellular view. In: Leathem, G. F. and Himmel, M. E. (Eds.). Enzymes in Biomass Conversion, ACS Symp. Series 460, American Chem. Soc., pp. 247-269. 
Silva, D.; Martins, E. S.; Silva, R. and Gomes, E (2002). Pectinase production from Penicillium viridicatum RFC3 by solid state fermentation using agricultural residues and agro-industrial by-product. Braz. J. Microbiol., 33, 318-324.

Soares, M. M. C. N.; Silva, R. and Gomes, E (1999) Screening of bacterial strains for pectinolytic activity characterization of the Pgase produced by Bacillus species. Rev. Microbiol., 30, 229-303.

Soares, M. M. C. N.; Silva, R.; Carmona, E. C. and Gomes, E. (2001), Pectinolytic enzymes production by Bacillus species and their potential application on juice extraction. World J. Microbiol. Biotechnol., 17, 79-82.

Zhen, Z. and Shetty, K (2000), Solid state production of polygalacturonase by Lentinus edodes using fruit processin wastes. Process Biochem., 35, 825-830.

Received: September 27, 2002; Revised: July 02, 2003 ; Accepted: July 02, 2004. 